TARBIYATUNA: Kajian Pendidikan Islam

Volume 3 Nomor 1 Tahun 2019

Print ISSN : 2597-4807

Online ISSN : 2622-1942

\title{
Pengaruh Motivasi Kerja Guru dan Keaktifan dalam MGMP terhadap Kreativitas Guru Ekonomi di SMA Se-Kota Malang
}

\author{
Lailatul Rofiah, \\ lailatulrofiah14@gmail.com \\ Universitas Islam Raden Rahmat Malang
}

\begin{abstract}
The main actor in education is a teacher. the task of the teacher is not only to enter the class, convey the subject matter, give assignments, then finish, but the teacher has the task of how the students who have diverse characteristics can be active and have creative thinking. Before transmitting their creativity to students, the teacher as an educator must know the creative potential that must be possessed. Teacher creativity can arise if the teacher is active in activities / training conducted at school or outside the school such as active activities in the MGMP, active in MGMP can arise if the teacher has high work motivation. The purpose of this study was to determine (1) the effect of teacher's work motivation on the creativity of economic teachers in high schools throughout the city of Malang, (2) the effect of MGMP activeness on the creativity of economic teachers in high schools throughout Malang, (3) the influence of teacher's work motivation and activeness in MGMP, towards the creativity of economic teachers in high schools throughout Malang. The results of this study are teacher work motivation and activeness in MGMP together have a significant effect on the creativity of economic teachers in high schools throughout Malang City. Related to this research, it is suggested that: the teacher develops his abilities and skills to prepare, implement and evaluate learning that is more creative and innovative again by following trainings carried out at school and outside the school.
\end{abstract}

Keywords: teacher work motivation, MGMP activity, teacher Creativity

\begin{tabular}{|c|c|c|}
\hline Accepted: & Reviewed: & Publised: \\
Desember 24 2018 & Januari 18 2019 & Februari 28 2019 \\
\hline
\end{tabular}

\section{PENDAHULUAN}

Pendidik pada zaman sekarang dituntut lebih kreatif dan inovatif sehingga tidak ketinggalan perkembangan zaman. Aktor utama dalam pendidikan adalah seorang guru. Guru adalah posisi yang strategis bagi pemberdayaan dan

This work is licensed under Creative Commons Attribution Non Commercial 4.0 International License Available iaiibrahimy.ac.id 
pembelajaran suatu bangsa yang tidak mungkin digantikan oleh unsur manapun dalam kehidupan sebuah bangsa sejak dahulu. Guru memiliki tugas yang beragam yang berimplementasi dalam bentuk pengabdian. Tugas tersebut meliputi bidang profesi, bidang kemanusiaan dan bidang kemasyarakatan (Mahmud, 2000:44).

Proses belajar mengajar merupakan inti dari proses pendidikan secara keseluruhan dengan guru sebagai pemegang peranan utama. Karena Proses belajar-mengajar mengandung serangkaian perbuatan pendidik/guru dan siswa atas dasar hubungan timbal balik yang berlangsung dalam situasi edukatif untuk mencapai tujuan tertentu. Sehingga seorang guru harus dituntut sekreatif mungkin agar dapat menciptakan suasana proses belajar yang menyenangkan dan tidak monoton.

Dalam pembelajaran di kelas, guru menjumpai berbagai macam anak dengan karakteristik mereka yang sangat beragam. Jadi tugas guru tidak hanya masuk kelas, menyampaikan materi pelajaran, memberikan tugas, kemudian selesai, tetapi guru mempunyai tugas bagaimana dari anak didik yang mempunyai karakteristik yang beragam dapat aktif dan memiliki pemikiran kreatif.Sebelum menularkan kreativitasnya terhadap anak didik, maka guru sebagai pendidik harus mengetahui potensi kreatif yang harus dimiliki, di mana potensi kreatif itu dapat dikembangkan yang membutuhkan beberapa cara salah satunya adalah seorang guru harus mempunyai berbagai informasi pengetahuan sebagai acuan berfikir karena dengan adanya berbagai pengetahuan, maka guru itu sendiri dapat menawarkan beberapa alternatif jawaban yang tentu saja dari informasi pengetahuan yang ia miliki (Darajat, 2005:23-24). Pengetahuan tersebut dapat diperoleh dari keaktifan guru dalam mengikuti Musyawarah Guru Mata Pelajaran (MGMP).

MGMP merupakan suatu wadah asosiasi atau perkumpulan bagi guru mata pelajaran yang berada disuatu sanggar, kabupaten/kota yang berfungsi sebagai sarana untuk saling berkomunikasi, belajar, dan bertukar pikiran dan pengalaman dalam rangka meningkatkan kreatifitas guru sebagai praktisi/pelaku perubahan berorientasi pembelajaran di kelas. Berdasarkan fungsi MGMP tersebut seharusnya guru dituntut untuk lebih aktif dalam mengikuti kegiatan-kegiatan yang ada di MGMP karena akan dapat meningkatkan kreatifitas guru.Karena kreativitas itu bukan benar-benar menciptakan sesuatu yang tidak ada menjadi ada, melainkan menghasilkan sesuatu yang ada menjadi hal yang baru dan asli dari pemikiran orang yang menciptakannya, disitulah letak kesepakatan dari semua pakar tentang kreativitas, yakni baru dan asli. Hal tersebut sesuai dengan pendapat Munandar (1985:89) yang mejelaskan tentang kreativitas merupakan kemampuan 
untuk membuat kombinasi baru, berdasarkan data, informasi atau unsur-unsur yang ada. Hasil yang diciptakan tidak selalu hal-hal yang baru, tetapi juga dapat berupa gabungan (kombinasi) dari hal-hal yang sudah ada sebelumnya.

Kenyataan yang ada dilapangan saat ini sebagai studi pendahuluan tentang kreatifitas guru berbeda dengan seharusnya yang ada. Banyak guru yang tidak kreatif khususnya sekolah-sekolah negeri. Sedangkan kreatifitas itu dipengaruhi dari dalam dirinya (internal) maupun di luar dirinya (eksternal). Salah satunya adalah kurang adanya kesiapan guru dalam penguasaan materi ketika mengajar di kelas sehingga para murid kurang memperoleh kedalaman ilmu, permaslahan lain yang muncul adalah minimnya guru untuk melakukan hal-hal yang inovatif dan kreatif untuk menunjang proses pembelajaran, selain itu banyak guru yang kurang memiliki motivasi kerja dalam melaksanakan tugasnya sebagai guru sehingga hal tersebut akan menghambat kekreatifan seorang guru. Kurang motivasi kerja tersebut terlihat dari masuk kelas sering terlambat, tugas-tugas guru tidak diselesaikan tepat waktu misalnya seperti pengumpulan nilai UAS dan UTS, pengumpalan RPP, Silabus, dan kurang aktifnya dalam mengikuti kegiatankegiatan yang diadakan di sekolah maupun di luar sekolah, contohnya seperti mengikuti kegiatan MGMP. Motivasi memang muncul dari dalam diri manusia, tetapi kemunculannya karena terangsang/terdorong oleh adanya unsur lain, dalam hal ini tujuan. Tujuan ini menyangkut soal kebutuhan (Sardiman, 1986:73).

Permasalahan ini patut mendapat perhatian khususnya guna untuk lebih memajukan lembaga pendidikan di Indonesia. Dengan adanya permasalahanpermasalahan itulah, peneliti bermaksud untuk menggali informasi lebih dalam tentang kreatifitas guru khususnya guru ekonomi. Robert (1992:201) menjelaskan bahwasanya kreatifitas ada beberapa faktor pengahambatnya di antaranya adalah takut gagal, ketidakmampuan mengenal masalah, lingkungan, terlalu cepat berpuas diri, pendirian yang tidak tetap dan lain sebagainya. Ada juga faktor pendukung di antaranya adalah lingkungan, motivasi untuk mengenal masalah, berani dan percaya diri adanya kesempatan untuk mendapatkan pengetahuan dan lain sebagainya. Berdasarkan faktor penghambat dan pendukung yang dikemukakan Robert tersebut, maka seorang guru untuk meningkatkan kreatifitasnya dalam mengelola kelas perlu motivasi kerja yang tinggi dalam melaksanakan tugasnya sebagai pendidik dan aktif dalam kegiatan MPGM karena kreatifitas juga dapat tumbuh karena adanya kesempatan untuk mendapatkan pengetahuan guna untuk meningkatkan kemampuannya dalam proses belajar mengajar (Munandar, 2009:27). Tujuan penelitian ini adalah untuk mengetahui 
pengaruh secara parsial maupun simultan motivasi kerja guru dan keaktifan dalam MGMP terhadap kreatifitas guru ekonomi di SMA se-Kota Malang.

\section{METODE PENELITIAN}

Rancangan penelitian yang digunakan dalam penelitian ini adalah penelitian eksplanatori. Populasi dalam penelitian ini adalah seluruh guru ekonomi SMA se-Kota Malang yang terdiri dari 10 SMA negeri dan 34 SMA swasta yang berjumlah 105 guru ekonomi. Sampel dalam penelitian ini berjumlah 60 guru ekonomi. Penelitian ini menggunakan teknik random sampling. Instrumen dalam penelitian ini adalah angket. Pengujian validitas pada instrumen menggunakan validitas isi (content validity) dan validitas konstruk. Dasar pengambilan keputusan tingkat reliabelitas adalah dengan metode Alpha Cronbach yang diukur berdasarkan skala alpha 0 sampai dengan 1 . Teknik pengumpulan data yang akan digunakan dalam penelitian ini adalah menggunakan teknik angket. Teknik analisis data menggunakan analisis deskriptif. Dalam membuktikan ada tidaknya pengaruh motivasi kerja guru dan keaktifan dalam MGMP terhadap kretifitas guru dengan menggunakan analisis regresi liner berganda SPSS 22.0 For Windows

Maka persamaan regresinya adalah sebagai berikut:

$$
Y=b_{0}+b_{1} \mathrm{X}_{1}+b_{2} \mathrm{X}_{2}+e
$$

Analisis selanjutnya adalah Koifisien determinasi $\left(R^{2}\right)$ pada intinya untuk mengukur seberapa jauh kemampuan model dalam menerangkan variasi variable dependen (Sudarmanto, 2004:160). Uji signifikansi F pada dasarnya menunjukkan apakah semua variable independen atau bebas yang dimasukkan dalam model mempunyai pengaruh secara bersama-sama terhadap variable dependen/terikat. Dan Uji $t$ untuk menunjukkan seberapa jauh pengaruh satu variable penjelas/independen secara individual dalam menerangkan variasi variable dependen (Sulhan, 2009:13).

\section{HASIL ANALISIS DAN PEMBAHASAN}

\section{A. Analisis Data}

Secara ringkas hasil analisis regresi linier berganda diuraikan dalam tabel 1.1 sebagai berikut.

Tabel 1. Ringkasan Hasil Analisis Regresi Liner Berganda

\begin{tabular}{|l|l|l|l|l|}
\hline $\begin{array}{l}\text { Motivasi } \\
\text { Kerja Guru }\end{array}$ & $-0,312$ & 0,000 & 0.163 & $\begin{array}{l}\text { Ha } \\
\text { ditolak }\end{array}$ \\
\hline
\end{tabular}




\begin{tabular}{|c|c|c|c|}
\hline $\begin{array}{l}\text { Keaktifan } \\
\text { di MGMP }\end{array}$ & 0,400 & 0,000 & $\begin{array}{l}\mathrm{Ha} \\
\text { diterima }\end{array}$ \\
\hline $\begin{array}{l}\text { Tingkat } \\
\text { signifikansi } \\
\text { Konstanta } \\
\text { Multiple R } \\
\text { R Square } \\
\text { Adjusted R } \\
\text { Square }\end{array}$ & $\begin{array}{l}0,05 \\
57.906 \\
0,518 \\
0,268 \\
0,243\end{array}$ & & \\
\hline
\end{tabular}

Berdasarkan Tabel 1 diatas dapat diperoleh persamaan regresi, hasil uji t, hasil uji F dan koefisien diterminasi sebagai berikut :

Persamaan regresi linier berganda yang diperoleh adalah sebagai berikut:

$\mathrm{Y}=57,906-0,312 \mathrm{X}_{1}+0,400 \mathrm{X}_{2}+\mathrm{e}$

Hasil uji hipotesis secara parsial (uji t) adalah sebagai berikut:

a. Dari hasil analisis menunjukkan bahwa secara parsial motivasi kerja guru mempunyai pengaruh negatif yang signifikan terhadap kreativitas guru ekonomi. Hal ini dapat dilihat dari hasil signifikansi t lebih besar dari 5\% (0,163 $>0,05)$ dan nilai B -312. Jadi diperoleh kesimpulan yaitu menolak $\mathrm{Ha}_{\mathrm{a}}$

b. Dari hasil analisis menunjukkan bahwa secara parsial keaktifan dalam MGMP mempunyai pengaruh positifyang signifikan terhadap kreatifitas guru. Hal ini dapat dilihat dari hasil signifikansi t lebih kecil dari $5 \%(0,000<0,05)$. Jadi diperoleh kesimpulan yaitu menerima $\mathrm{H}_{\mathrm{a}}$

Hasil uji hipotesis secara simultan (uji F) adalah sebagai berikut:

a. Signifikansi $\mathrm{F}<5 \%$ yaitu $=0,000<0,05$. Hal ini berarti bahwa secara bersamasama variabel motivasi kerja guru (X1), dan keaktifan di MGMP (X2) mempunyai pengaruh yang signifikan terhadap variabel kreatifitas guru ekonomi.

b. Nilai Adjusted $R$ Square sebesar 0,518 Dapat diinterprestasikan bahwa variabel motivasi kerja guru dan keaktifan di MGMP, dalam mempengaruhi kreatifitas guru ekonomi di sekolah Menengah Atas se Kota Malang sebesar 51,8\% dan sisanya sebesar 48,2\% dipengaruhi oleh variabel lain diluar penelitian.

\section{B. Pembahasan}

1. Pengaruh motivasi kerja guru terhadap kreatifitas guru ekonomi di SMA se-Kota Malang 
Motivasi kerja guru dalam penelitian ini adalah dorongan yang tumbuh dari diri seseorang baik yang berasal dari luar maupun dari dalam dirinya untuk melakukan pekerjaan dengan semangat tinggi menggunakan semua kemampuan yang dimilikinya yang bertujuan untuk mendapatkan hasil kerja sehingga mencapai kepuasan sesuai dengan keinginannya (As'ad, 1995:111). Bekerja mengandung arti melaksankan suatu tugas yang diakhiri dengan buah karya yang dapat dinikmati oleh manusia yang bersangkutan. Faktor utama yang menyebabkan manusia bekerja adalah adanya kebutuhan yang harus dipenuhi. Motivasi memang muncul dari dalam diri manusia, tetapi kemunculannya karena terangsang/terdorong oleh adanya unsur lain, dalam hal ini tujuan. Tujuan ini menyangkut soal kebutuhan (Sardiman, 1986:73). Purwanto juga menjelaskan motivasi merupakan suatu pernyataan yang kompleks di dalam suatu organisme yang mengarahkan tingkah laku terhadap suatu tujuan (goal) atau perangsang (intensive) (Purwanto, 2006:38).

Hasil penelitian menunjukkan bahwa motivasi kerja guru berpengaruh negatif yang signifikan terhadap kreatiftas guru ekonomi. Pengaruh negatif tersebut dikarenakan: 1) pihak sekolah kurang memberi penghargaan bagi guru yang berpretasi, dan tidak memberikan peringatan/hukuman pada guru yang kurang maksimal dalam menjalankan tugasnya sebagai pendidik misalnya seperti ketidakdisiplinan guru; 2) kurangnya insentif dari pihak sekolah misalnya tidak ada tambahan gaji bagi yang kerja lembur atau mengerjakan tugas selain mengajar; 3) ada rekan kerja yang tidak menyenangkan; 4) birokrasi sekolah yang terlalu kaku sehingga guru merasa tidak nyaman, empat hal tersebut diperjelas dengan penjelasan beberapa guru yang diperoleh peneliti pada waktu pengisian angket dan wawancara terhadap guru.

\section{Pengaruh keaktifan dalam MGMP terhadap kreatifitas guru ekonomi di SMA se-Kota Malang \\ Hasil penelitian menunjukkan bahwasannya ketika seorang guru aktif} mengikuti kegiatan-kegiatan MGMP maka akan dapat meningkatkan kreatifitas guru ekonomi dalam hal pengelolaan pembelajaran, penguasaan materi ekonomi, dan juga dapat meningkatkan kemampuan dan keterampilan dalam mempersiapkan, melaksanakan dan mengevaluasi, meningkatkan kompetensikompetensi guru lainnya misalkan seperti pengembangan bahan ajar, inovasi media pembelajaran dan lain-lain. Hal tersebut diperkuat dengan hasil angket dengan indikator keaktifan dalam MGMP yang dikembangkan peneliti.

Keaktifan dalam mengikuti MGMP merupakan sejauh mana guru ekonomi berperan serta dan berpartisipasi aktif dalam kegiatan yang terdapat dalam 
MGMP. MGMP merupakan suatu wadah asosiasi atau perkumpulan bagi guru mata pelajaran yang berada disuatu sanggar, kabupaten/kota yang berfungsi sebagai sarana untuk saling berkomunikasi, belajar, dan bertukar pikiran dan pengalaman dalam rangka meningkatkan kreatifitas guru sebagai praktisi/pelaku perubahan berorientasi pembelajaran dikelas.

\section{Pengaruh motivasi kerja guru dan keaktifan dalam MGMP terhadap kreatifitas guru ekonomi di SMA se-Kota Malang}

Dari hasil analisis uji F motivasi kerja guru dan keaktifan dalam MGMP secara simultan berpengaruh signifikan terhadap kreatifitas guru ekonomi di SMA se-Kota Malang Kreatifitas guru ekonomi khususnya dalam penguasaan materi dan pengelolaan kelas dapat dipengaruhi oleh faktor dalam diri guru maupun di luar diri guru. Dalam penelitian ini yang termasuk dalam faktor dalam diri guru adalah motivasi kerja guru yang bisa timbul dari faktor internal guru tersebut atau dari faktor ekternal sedangkan keaktifan dalam mengikuti MGMP juga termasuk faktor internal guru tersebut Hal ini sesuai dengan teori yang diungkapkan Robert bahwasanya kreatifitas ada beberapa faktor pengahambatnya di antaranya adalah takut gagal, ketidakmampuan mengenal masalah, lingkungan, terlalu cepat berpuas diri pendirian yang tidak tetap dan lain sebagainya, tetapi juga ada faktor pendukungnya di antaranya adalah lingkungan, motivasi untuk mengenal masalah, berani dan percaya diri adanya kesempatan untuk mendapatkan pengetahuan dan lain sebagainya (Robert, 1992:201).

Pengaruh signifikan tersebut dikarenakan jika motivasi kerja guru meningkat baik itu motivasi yang timbul dari faktor internal seperti dorongan diri sendiri dalam melaksanakan tugasnya sebagai pendidik maupun ekternal seperti adanya penghargaan guru berprestasi, hukuman bagi guru yang kurang aktif ataupun insentif kerja sehingga berimplikasi terhadap keaktifan guru dalam mengikuti MGMP. Jadi dapat disimpulkan bahwa kedua variabel tersebut secara bersama-sama berpengaruh terhadap kreatifitas guru ekonomi tetapi harus didukung dengan birokrasi sekolah yang tidak kaku, dan membuat kondisi sekolah senyaman mungkin.

Pada dasarnya masih adalagi faktor- faktor lain yang mempengaruhi kreatifitas guru. Meskipun secara simultan motivasi kerja guru dan keaktifan dalam MGMP memiliki pengaruh terhadap kreatifitas guru sebesar 51,8\% tetapi masih ada sebesar 48,2\% dijelaskan oleh variabel lain di luar model yang juga mempengaruhi kreatifitas guru. 


\section{SIMPULAN}

Hasil penelitian menunjukkan bahwa secara parsial motivasi kerja guru terhadap kreatifitas guru ekonomi di SMA se-Kota Malang tidak berpengaruh signifikan namun secara simultan motivasi kerja guru dan keaktifan dalam MGMP berpengaruh signifikan terhadap kreatifitas guru ekonomi di SMA se- Kota Malang.

Bagi guru sebaiknya guru mengembangkan kemampuannya dan keterampilannya untuk mempersiapkan, melaksanakan dan mengevaluasi pembelajaran yang lebih kreatif dan inovatif lagi dengan cara mengikuti pelatihanpelatihan yang dilaksanakan di sekolah maupun di luar sekolah. Bagi peneliti selanjutnya yang akan melakukan penelitian sejenis diharapkan dapat menggunakan hasil penelitian ini sebagai dasar atau referensi penelitian disertai pengembangan masalah dari sudut yang berbeda.

\section{DAFTAR RUJUKAN .}

As'ad, Muhammad. (1995). Psikologi Industri. Yogyakarta: Liberty

Darajat, Zakiyah. (2005). Kepribadian Guru. Jakarta: PT Bulan Bintang

Mahmud, Dimyati. (2000). Psikologi Pendidikan. Yogyakarta: B PFE

Munandar, Utami. (1985). Anak-Anak Berbakat, Pembinaan dan Pendidikannya. Jakarta: Rajawali

Munandar, Utami. (2009). Pengembangan Kreativitas Anak Berbakat. Jakarta: Rineka Cipta

Purwanto, Ngalim. (2006). Psikologi Pendidikan. Bandung: PT Remaja Rosdakarya

Sardiman, A. M. (1986). Interaksi dan Motivasi Belajar Mengajar. Jakarta: CV.Rajawali

Sulhan, Muhammad. (2009). Panduan Praktis Analisis SPSS untuk Manajemen (Keuangan, SDM dan Pemasaran). Malang: UIN

Sudarmanto, Gunawan. (2004). Analisis Regresi Linier Ganda dengan SPSS. Yogyakarta: Graha Ilmu

Robert, W. Olson. (1992). Seni Berfikir Kreatif Pedoman Praktis. Jakarta: Erlangga 